\title{
Supporting Information for: Chemical probes for the rapid detection of fatty-acylated proteins in mammalian cells
}

\author{
Howard C. Hang ${ }^{1}$, Ernst-Jan Geutjes ${ }^{1}$, Gijsbert Grotenbreg ${ }^{1}$, Annette M. Pollington ${ }^{1}$, \\ Marie Jose Bijlmakers ${ }^{2}$, Hidde L. Ploegh ${ }^{1}$ \\ ${ }^{1}$ Whitehead Institute for Biomedical Research and Department of Biology, \\ Massachussetts Institute of Technology, Cambridge, MA 02137 \\ and \\ ${ }^{2}$ Department of Immunobiology, Guy's Hospital, \\ King's College London, London SE1 9RT, United Kingdom
}

Correspondence:ploegh@wi.mit.edu 
Chemical synthesis of $\omega$-azido-fatty acids. The chemical synthesis of the $\omega$-azido-fatty acids (1-4) is shown in Scheme 1. Commercially available $\omega$-hydroxy fatty acids were converted to corresponding methyl esters with acetyl chloride $(\mathrm{AcCl})$ and methanol $(\mathrm{MeOH})$ in good yield. The $\omega$-hydroxy fatty acid methyl esters were then reacted with mesyl chloride $(\mathrm{MsCl})$ and triethylamine (TEA) to afford the corresponding $\omega$-mesylfatty acid methyl esters, which were displaced with sodium azide in $N, N$-dimethyl formamide (DMF). The resulting $\omega$-azido-fatty acid methyl esters were saponified with 1 M sodium hydroxide (NaOH) in tetrahydrofuran (THF):water (1:1) to yield the $\omega$-azidofatty acids (1-4) in good yield.<smiles>CCCCCCCCCCCCCCCO</smiles>
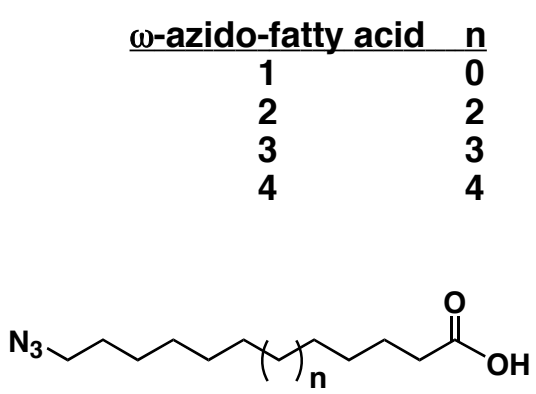

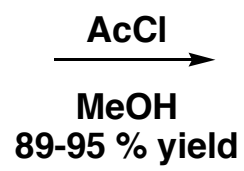

$89-95 \%$ yield
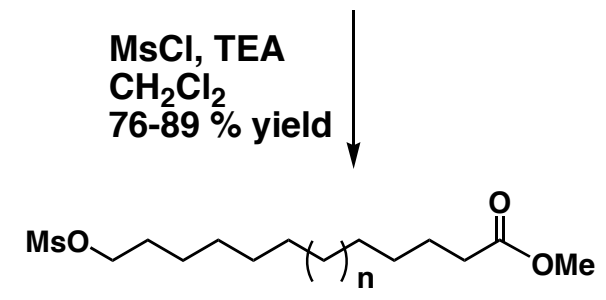

$1 \mathrm{M} \mathrm{NaOH}$

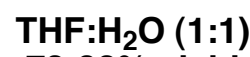
$73-82 \%$ yield
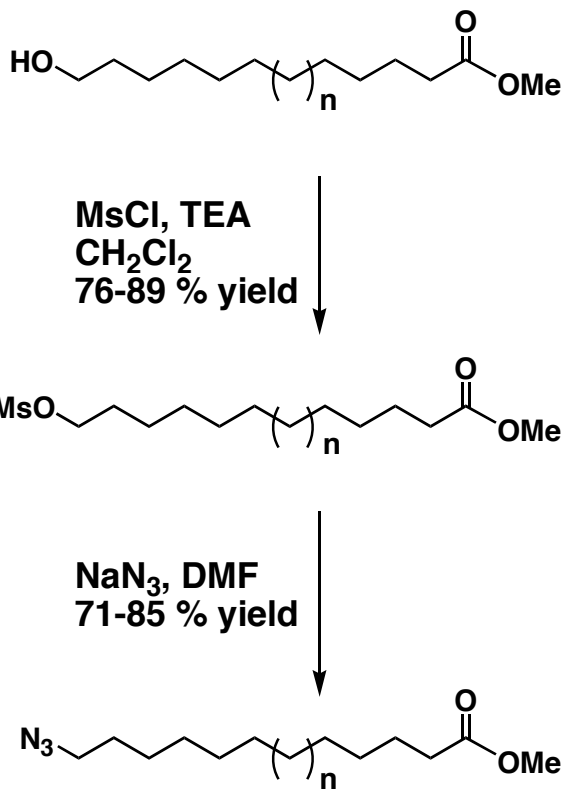

Supporting Information Scheme 1. Chemical synthesis of $\omega$-azido-fatty acids. 
General procedure for the synthesis of $\omega$-azido-fatty acids. All chemicals were obtained from commercial suppliers and were used as received unless otherwise noted. The silica gel used in flash column chromatography was Merck No. $938560 \AA$, 230-400 mesh. Analytical thin layer chromatography (tlc) was conducted on Analtech Uniplate silica gel plates with detection by ceric ammonium molybdate, triphenylphosphine/ninhydrin or UV light. The ${ }^{1} \mathrm{H}-\mathrm{NMR}$ and ${ }^{13} \mathrm{C}-\mathrm{NMR}$ spectra were obtained at 400 and $100 \mathrm{MHz}$, respectively, with a Bruker-400 spectrometer. Chemical shifts are reported in $\delta \mathrm{ppm}$ values downfield from tetramethylsilane and $J$ values are reported in Hz. Low-resolution electrospray ionization (ESI) mass spectra were obtained with Waters-Micromass LCT.

To a $25 \mathrm{~mL}$ round-bottom flask was added an $\omega$-hydroxy fatty acid ( $2 \mathrm{mmol})$, $\mathrm{MeOH}(5 \mathrm{~mL})$ and $\mathrm{AcCl}(10 \mathrm{mmol})$. The solution was stirred for $3 \mathrm{hr}$ at $\mathrm{rt}$ and concentrated. The resulting white solids were resuspended in $\mathrm{CH}_{2} \mathrm{Cl}_{2}(50 \mathrm{~mL})$, washed with $\mathrm{NaHCO}_{3}(2 \times 50 \mathrm{~mL})$ and brine $(50 \mathrm{~mL})$. The organic phase was separated, dried over $\mathrm{Na}_{2} \mathrm{SO}_{4}$ and concentrated to afford the corresponding $\omega$-hydroxy fatty acid methyl esters in excellent yield (89-95\%).

The $\omega$-hydroxy fatty acid methyl ester $(2 \mathrm{mmol})$ was dissolved in anhydrous $\mathrm{CH}_{2} \mathrm{Cl}_{2}(10 \mathrm{~mL})$ in $50 \mathrm{~mL}$ round-bottom flask. To the solution was added TEA (2.2 mmol), the flask was placed in ice-bath of $30 \mathrm{~min}$ and $\mathrm{MsCl}(2.2 \mathrm{mmol})$ was added dropwise. The reaction mixture was allowed to stir for $30 \mathrm{~min}$ in the ice-bath and $1 \mathrm{hr}$ at rt. The reaction mixture was then diluted with $\mathrm{CH}_{2} \mathrm{Cl}_{2}(50 \mathrm{~mL})$, washed with deionized water $(50 \mathrm{~mL}), \mathrm{NaHCO}_{3}(2 \times 50 \mathrm{~mL})$ and brine $(50 \mathrm{~mL})$. The organic phase was 
separated, dried over $\mathrm{Na}_{2} \mathrm{SO}_{4}$ and concentrated to afford the corresponding $\omega$-mesyl fatty acid methyl esters as white solids in good yield (76-89\%).

To a $50 \mathrm{~mL}$ round-bottom flask was added a $\omega$-mesyl fatty acid methyl ester (2 mmol), anhydrous dimethyl formamide (DMF, $10 \mathrm{~mL})$ and sodium azide $(10 \mathrm{mmol})$. The solution was stirred for $16 \mathrm{hr}$ at $45^{\circ} \mathrm{C}$, cooled to $\mathrm{rt}$ and concentrated. The crude material was resuspended with $\mathrm{CH}_{2} \mathrm{Cl}_{2}(50 \mathrm{~mL})$, washed with deionized water ( $3 \times 50$ $\mathrm{mL})$ and brine $(50 \mathrm{~mL})$. The organic phase was separated, dried over $\mathrm{Na}_{2} \mathrm{SO}_{4}$ and concentrated. The crude material was purified by silica gel flash chromatography eluting with 10:1 hexanes:ethyl acetate (EtOAc) to afford $\omega$-azido fatty acid methyl esters in good yield (71-85\%).

To a $50 \mathrm{~mL}$ round-bottom flask were added an $\omega$-azido fatty acid methyl ester (2 mmol), THF $(10 \mathrm{~mL})$ and deionized water $(10 \mathrm{~mL}) .1 \mathrm{M} \mathrm{NaOH}(10 \mathrm{mmol})$ was then added dropwise and reaction mixture was stirred for $16 \mathrm{hr}$ at $\mathrm{rt}$. The reaction mixture were diluted with EtOAc $(50 \mathrm{~mL})$, washed with $10 \% \mathrm{HCl}(25 \mathrm{~mL})$ washed with deionized water $(2 \times 50 \mathrm{~mL})$ and brine $(50 \mathrm{~mL})$. The organic phase was separated, dried over $\mathrm{Na}_{2} \mathrm{SO}_{4}$ and concentrated to afford the corresponding $\omega$-azido fatty acids (1-4) in good yield (73-82\%).

w-azido-dodecanoic acid (1). ${ }^{1} \mathrm{H}-\mathrm{NMR}\left(400 \mathrm{MHz}, \mathrm{CDCl}_{3}\right) \delta 3.27(\mathrm{t}, 2, J=7.0), 2.36(\mathrm{t}$, 2, $J=7.5), 1.63(\mathrm{~m}, 4), 1.29(\mathrm{~m}, 14) .{ }^{13} \mathrm{C}-\mathrm{NMR}\left(100 \mathrm{MHz}, \mathrm{CDCl}_{3}\right) \delta$ 180.4, 51.4, 34.1, 29.4, 29.4, 29.3, 29.2, 29.1, 29.0, 28.8, 26.7, 24.6. ESI-LRMS calcd. for $\mathrm{C}_{12} \mathrm{H}_{24} \mathrm{NO}_{2}(\mathrm{M}-$ $\mathrm{N}_{2}+\mathrm{H}^{+}$) 214.18, found 214.18. 
$\boldsymbol{\omega}$-azido-tetradecanoic acid (2). ${ }^{1} \mathrm{H}-\mathrm{NMR}\left(400 \mathrm{MHz}, \mathrm{CDCl}_{3}\right) \delta 3.27$ (t, $\left.2, J=7.0\right), 2.37$ $(\mathrm{t}, 2, J=7.5), 1.64(\mathrm{~m}, 4), 1.28(\mathrm{~m}, 18) .{ }^{13} \mathrm{C}-\mathrm{NMR}\left(100 \mathrm{MHz}, \mathrm{CDCl}_{3}\right) \delta 179.8,51.4$, 51.4, 34.0, 29.7, 29.5, 29.5, 29.5, 29.4, 29.2, 29.1, 28.8, 26.7, 24.6. ESI-LRMS calcd. for $\mathrm{C}_{14} \mathrm{H}_{28} \mathrm{NO}_{2}\left(\mathrm{M}-\mathrm{N}_{2}+\mathrm{H}^{+}\right)$242.21, found 242.20.

w-azido-pentadecanoic acid (3). ${ }^{1} \mathrm{H}-\mathrm{NMR}\left(400 \mathrm{MHz}, \mathrm{CDCl}_{3}\right) \delta 3.27$ (t, 2, $\left.J=7.0\right), 2.36$ $(\mathrm{t}, 2, J=7.5), 1.63(\mathrm{~m}, 4), 1.29(\mathrm{~m}, 20) .{ }^{13} \mathrm{C}-\mathrm{NMR}\left(100 \mathrm{MHz}, \mathrm{CDCl}_{3}\right) \delta 180.2,51.4$, 34.1, 29.6, 29.6, 29.5, 29.5, 29.4, 29.4, 29.4, 29.2, 29.1, 29.0, 26.7, 24.6. ESI-LRMS calcd. for $\mathrm{C}_{15} \mathrm{H}_{30} \mathrm{NO}_{2}\left(\mathrm{M}-\mathrm{N}_{2}+\mathrm{H}^{+}\right)$256.22, found 256.24.

w-azido-hexadecanoic acid (4). ${ }^{1} \mathrm{H}-\mathrm{NMR}\left(400 \mathrm{MHz}, \mathrm{CDCl}_{3}\right) \delta 3.27(\mathrm{t}, 2, J=7.0), 2.37$ $(\mathrm{t}, 2, J=7.5), 1.62(\mathrm{~m}, 4), 1.28(\mathrm{~m}, 22) .{ }^{13} \mathrm{C}-\mathrm{NMR}\left(100 \mathrm{MHz}, \mathrm{CDCl}_{3}\right) \delta$ 179.9, 51.4, $34.0,29.6,29.6,29.5,29.5,29.5,29.4,29.4,29.4,29.2,29.1,29.0,26.7,24.6$. ESILRMS calcd. for $\mathrm{C}_{16} \mathrm{H}_{32} \mathrm{NO}_{2}\left(\mathrm{M}-\mathrm{N}_{2}+\mathrm{H}^{+}\right)$270.24, found 270.23 .

Cell Culture. RAW264.7 macrophages, NIH3T3 fibroblasts were cultured in petri dishes in DMEM media supplemented with 10\% fetal calf serum (FCS), penicillin (100 units $/ \mathrm{mL})$ and streptomycin $(0.1 \mathrm{mg} / \mathrm{mL})$. Jurkat $\mathrm{T}$ cells were cultured in tissue culture flasks in RPMI media supplemented with 10\% FCS, penicillin (100 units $/ \mathrm{mL}$ ) and streptomycin $(0.1 \mathrm{mg} / \mathrm{mL})$. Cells were incubated in a $5 \% \mathrm{CO}_{2}$ humidified incubator at 37 ${ }^{\circ} \mathrm{C}$. 
Metabolic labeling. The $\omega$-azido fatty acids were dissolved in DMSO to generate 50 mM stock solutions. Fatty acids were added to DMEM or RPMI media supplemented with 5\% dialyzed FCS and allowed to pre-complex for 15 min at rt. If necessary, the fatty acid-media solutions were sonicated to dissolve lipids. Fatty acid-media solutions were then added to cells and incubated for times indicated at $37{ }^{\circ} \mathrm{C}$ in a $5 \% \mathrm{CO}_{2}$ humidified incubator. Cells were harvested washed with PBS and lysed with NP-40 lysis buffer (50 mM Tris pH 7.4, $5 \mathrm{mM} \mathrm{MgCl}{ }_{2}, 0.5 \%$ NP-40, EDTA protease inhibitor cocktail (Roche)) at $4{ }^{\circ} \mathrm{C}$. Cell lysates were centrifuged at $20,000 \mathrm{~g}$ for $10 \mathrm{~min}$ at $4{ }^{\circ} \mathrm{C}$ to remove cell debris to afford post-nuclear cell lysates. For competition experiments with cold fatty acids, lauric acid (12), myristic acid (14), palmitic acid (16) or stearic acid (18) were dissolved in DMSO to generate $50 \mathrm{mM}$ stock solutions. The cold fatty acids were coincubated with $\omega$-azido-fatty acids in 5\% dialyzed FCS cell culture media (DMEM or RPMI) at the concentrations indicated and used for metabolic labeling as described above.

Visualization of azide-modified proteins by streptavidin blot. Post-nuclear cell lysates (100 $\mu \mathrm{g}$, protein concentration determined by Bradford assay) were reacted with phosphine-biotin (200 $\mu \mathrm{M}, 10 \mathrm{mM}$ stock solution in DMSO), synthesized as previously described (6), DTT (5 mM, $100 \mathrm{mM}$ stock solution in deionized $\mathrm{H}_{2} \mathrm{O}$ ) in a total reaction of volume of $100 \mu \mathrm{L}$ for $2 \mathrm{hr}$ at $37{ }^{\circ} \mathrm{C}$. DTT is included in the labeling reactions to prevent non-specific oxidation of phosphine-biotin, which can increase levels of background labeling. The reactions were terminated by the addition of ice-cold acetone $(1 \mathrm{~mL})$ and placed at $-20{ }^{\circ} \mathrm{C}$ for at least $30 \mathrm{~min}$, centrifuged at $20,000 \mathrm{~g}$ for $10 \mathrm{~min}$ at $4{ }^{\circ} \mathrm{C}$ 
to precipitate proteins. The supernatant from the samples were discarded. The protein pellets were allowed to air dry for $10 \mathrm{~min}$, resuspended in $1 \mathrm{X}$ non-reducing SDS-sample buffer (10\% glycerol, 60 mM Tris- $\mathrm{HCl}$ pH 6.8, 2\% SDS, $0.025 \%$ bromophenol blue), heated for $5 \mathrm{~min}$ at $90{ }^{\circ} \mathrm{C}$. Proteins were then seperated by SDS-PAGE using $10 \%$ acrylamide gel and transferred to a nitrocellulose membrane, which was blocked with PBST (PBS, 0.1\% Tween-20) containing 5\% non-fat dried milk for $1 \mathrm{hr}$ at $\mathrm{rt}$ or overnight at $4{ }^{\circ} \mathrm{C}$. The membrane was washed with PBST $(3 \mathrm{x})$ and incubated with streptavidinhorseradish peroxidase (1:5000 in PBST, Amersham) for $1 \mathrm{~h}$ at $\mathrm{rt}$. The membrane was washed wish PBST (3x) and subsequently developed with enhanced chemiluminescence substrate (PerkinElmer). For the hydroxylamine-sensitive assay, following transfer of proteins to nitrocellulose membranes, membranes were incubated with PBST with 5\% aqueous $\mathrm{NH}_{2} \mathrm{OH}$ (Sigma-Aldrich) prior to blocking and analyzed by streptaviding blot as described above. To demonstrate equal levels of protein loading, streptavidin blots were inactivated with $\mathrm{H}_{2} \mathrm{O}_{2}$ and probed with anti- $\beta$-actin antibody followed by rabbit antimouse HRP.

Immunoprecipitation of Lck. For the analysis of endogenous levels Lck, Jurkat T cell were metabolically labeled with $\omega$-azido fatty acids as described above. For the analysis of wild-type Lck and G2A mutant Lck, HEK293T cells were transfected with cDNAs encoding the corresponding Lck constructs, previously described (10), using the calcium phosphate method $24 \mathrm{hr}$ prior to metabolic labeling with $\omega$-azido fatty acids. Postnuclear lysates were prepared and reacted with phosphine-biotin as described above. After acetone precipitation of the cell lysates, protein pellets were resuspended in NP-40 
lysis buffer containing $0.2 \%$ SDS with sonication to a protein concentration of $\sim 1$ $\mathrm{mg} / \mathrm{mL}$. Resuspended cell lysates were then incubated with $2 \mu \mathrm{L}$ of polyclonal rabbit anti-Lck sera (9), $30 \mu \mathrm{L}$ of protein A beads (RepliGen, prewashed with NP-40 lysis buffer $3 \mathrm{x}$ ) and incubated for $1 \mathrm{~h}$ at $4{ }^{\circ} \mathrm{C}$ with rocking. The protein $\mathrm{A}$ beads were centrifuged at 3,000 $\mathrm{x}$ g for $1 \mathrm{~min}$ at $4{ }^{\circ} \mathrm{C}$ and supernatant was discarded. The remaining protein A beads were washed NP-40 lysis buffer with $0.2 \%$ SDS (4x), resuspended in $1 \mathrm{X}$ SDS-sample buffer, heated for $5 \mathrm{~min}$ at $90{ }^{\circ} \mathrm{C}$, seperated by SDS-PAGE and analyzed by streptavidin blot as described above. Immunoblots for Lck blots were performed by incubation of nitrocellulose membranes with monoclonal mouse anti-Lck antibody (1:2000, Upstate, Clone 3A5) in PBST 5\% non-fat dried milk for $1 \mathrm{hr}$ at $\mathrm{rt}$. Membranes were washed with PBST (3x), incubated with polyclonal anti- mouse IgG Kappa antibody (1:30,000, Amersham) in PBST 5\% non-fat dried milk for $1 \mathrm{hr}$ at rt. Membranes were washed with PBST (3x) and subsequently developed with enhanced chemiluminescence substrate (PerkinElmer). 


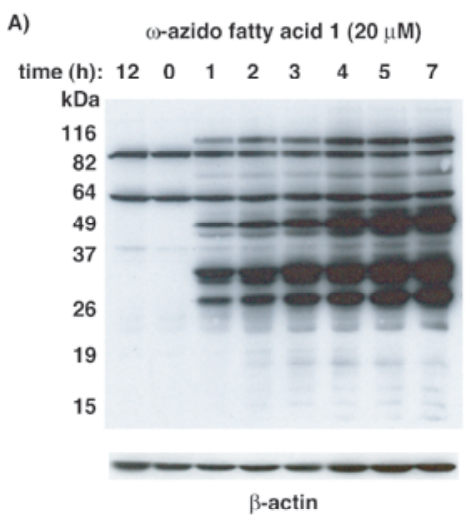

B)

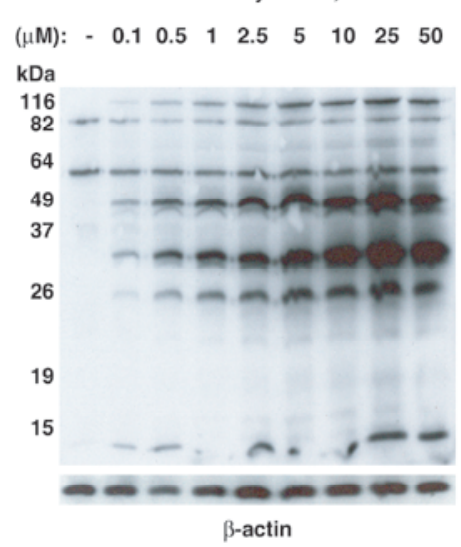

$\omega$-azido fatty acid $2(50 \mu \mathrm{M})$

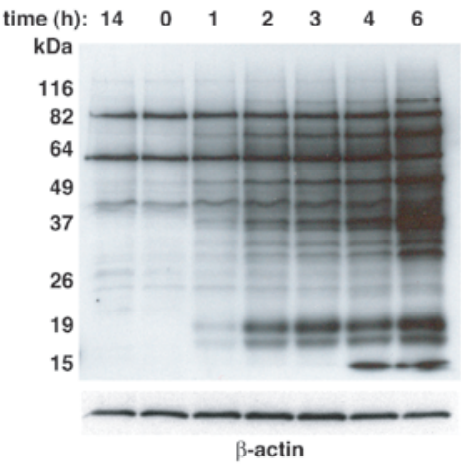

(1)-azido fatty acid $2,4 \mathrm{~h}$
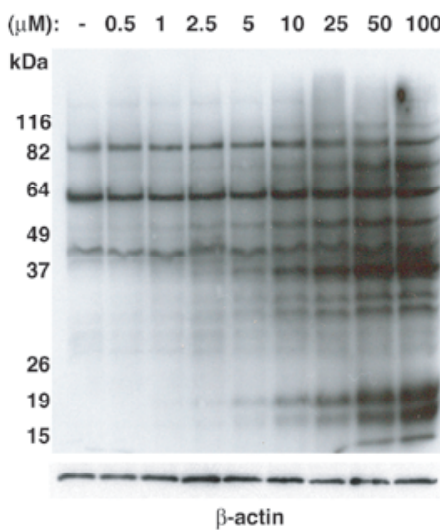

(w-azido fatty acid $3(200 \mu \mathrm{M})$

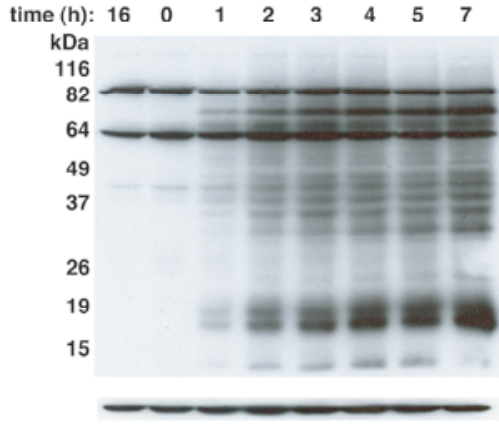

$\beta$-actin

w-azido fatty acid $3,4 \mathrm{~h}$

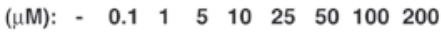

kDa

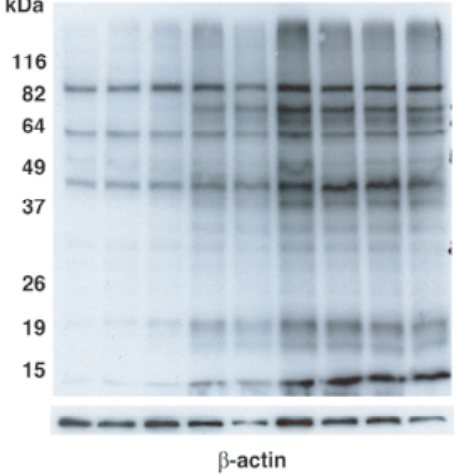

Supporting Information Figure 1. Characterization of $\omega$-azido-fatty acids protein labeling in RAW264.7 macrophages. A) Time-dependent labeling of proteins with $\omega$ azido-fatty acids 1, 2 and 3. B) Dose-dependent labeling of proteins with $\omega$-azido-fatty acids $\mathbf{1}, \mathbf{2}$ and $\mathbf{3}$. Cells were incubated with various $\omega$-azido-fatty-acids or DMSO control (-) under conditions indicated and harvested. Post-nuclear cell lysates were prepared and reacted with phosphine-biotin $(200 \mu \mathrm{M})$, DTT $(5 \mathrm{mM})$ for $2 \mathrm{hr}$ at $37{ }^{\circ} \mathrm{C}$, separated by gelelectrophoresis and analyzed by streptavidin blot. Endogenously biotinylated proteins serve as internal controls for protein loading. Furthermore, streptavidin blots were stripped and reprobed for $\beta$-actin levels to demonstrate comparable levels of protein loading. 

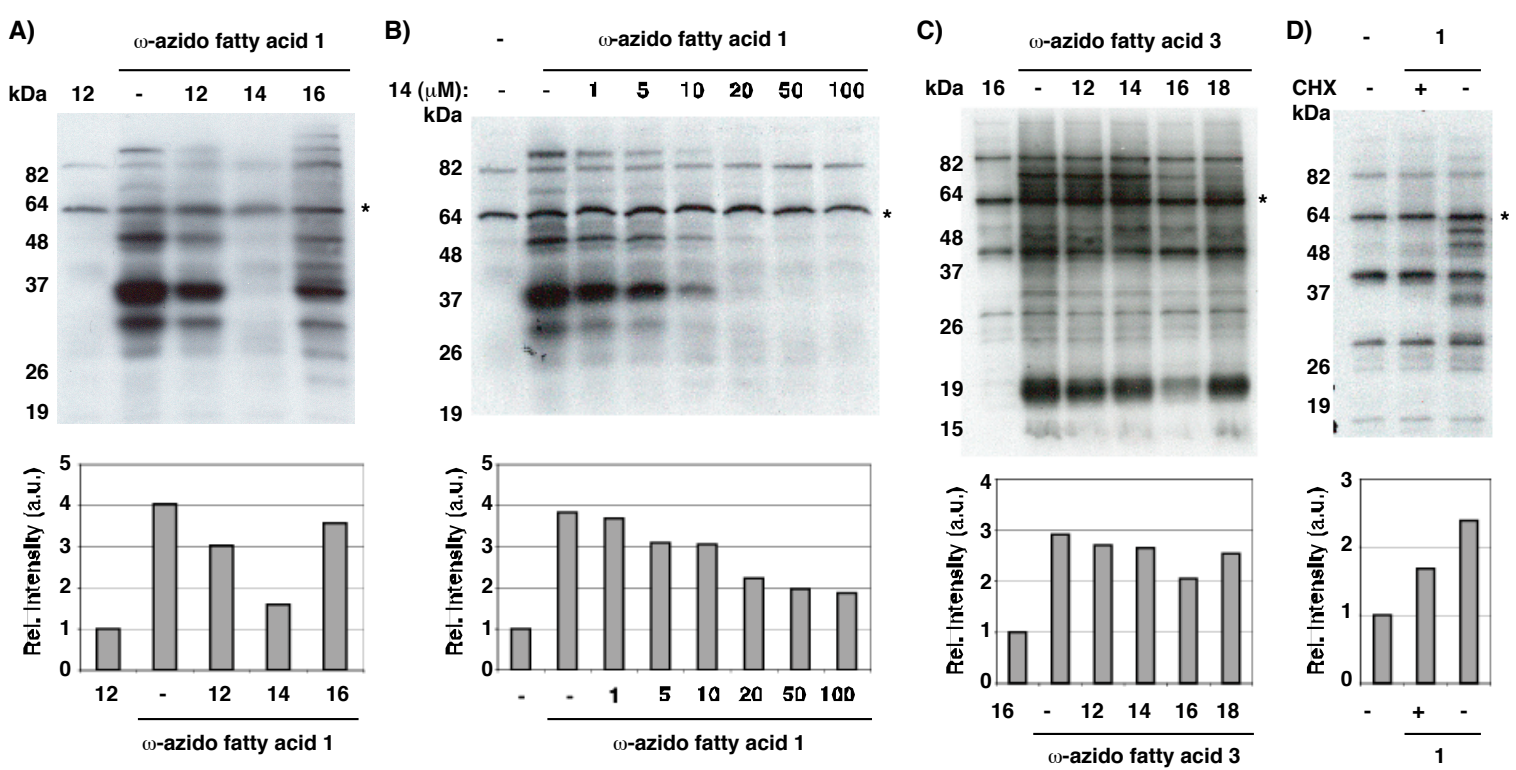

Supporting Information Figure 2. Selectively of $\omega$-azido-fatty acid protein labeling in RAW264.7 macrophages. A) Coincubation of $\omega$-azido-fatty acid $\mathbf{1}(10 \mu \mathrm{M})$ with cold fatty acids $(50 \mu \mathrm{M})$. As a negative control cells were fed with lauric acid $12(10 \mu \mathrm{M})(-)$. B) Dose-dependent competition of $\omega$-azido-fatty acid 1 labeling with myristic acid (14).

C) Coincubation of $\omega$-azido-fatty acid $3(50 \mu \mathrm{M})$ with cold fatty acids $(250 \mu \mathrm{M})$, lauric acid (12), myristic acid (14), palmitic acid (16), stearic acid (18). As a negative control cell were fed palmitic acid $16(50 \mu \mathrm{M})$. D) Cycloheximide (CHX) inhibition of $\omega$-azidofatty acid 1 protein labeling. Cells were incubated with DMSO (-/-), $\omega$-azido-fatty acid 1 $(20 \mu \mathrm{M})(-/ 1)$ or $\omega$-azido-fatty acid $1(20 \mu \mathrm{M})$ with $\mathrm{CHX}(1 \mu \mathrm{M})(+/ 1)$. Cells were incubated with fatty acids for $4 \mathrm{hr}$ and analyzed for $\omega$-azido-fatty acid protein labeling by streptavidin blotting as described above. Endogenously biotinylated proteins serve as internal controls for protein loading. The extent of $\omega$-azido-fatty acid protein labeling in each lane visualized by streptavidin blotting was quantified using ImageJ software. The total pixel intensity of each lane was measured and normalized to the pixel intensity of the endogenously biotinylated protein at $\sim 64 \mathrm{kDa}$ (indicated on each blot by $*$ ) and reported in relative intensity in arbitrary units. 